\title{
Cardiac arrest following inhalation induction of anaesthesia in a child with Duchenne's muscular dystrophy
}

Cardiac arrest occurred in a 5t-year-old child with suspected Duchenne's muscular dystrophy ten minutes following induction of anaesthesia with halothane, nitrous oxide and oxygen. No muscle relaxants were administered. The cardiac arrest was associated with hyperkalaemia, acidosis, myoglobinuria, elevated serum creatine phosphokinase and a $1.6^{\circ} \mathrm{C}$ rise in temperature. The child made a complete recovery after receiving 90 minutes of cardiopulmonary resuscitation.

Malignant hyperthermia (MH) has developed during anaesthesia in a number of children with Duchenne's muscular dystrophy (DMD). ${ }^{1-7}$ Most cases have occurred after prolonged use of halothane or following administration of succinylcholine.

In this report, we describe a child with suspected DMD who developed sudden cardiac arrest during induction of anaesthesia with halothane, nitrous oxide and oxygen.

\section{Key words}

ANAESTHESTA, COMPLICATIONS: cardiac arrest, malignant hyperthermia, Duchenne's muscular dystrophy.

From the Department of Anesthesia, The Children's Hospital, Harvard Medical School, 300 Longwood Avenue, Boston, Massachusetts 02115 U.S.A. Address correspondence to: Dr. Sethna.

\section{Case report}

A $5 \frac{1}{2}$-year-old boy was scheduled for an elective muscle biopsy. He presented with progressive weakness, an awkward gait and complaints of calf pain. His past medical history and physical examination were unremarkable except for proximal muscle weakness. The clinical diagnosis was probable DMD. There was no evidence of cardiac disease and a preoperative electrocardiogram (ECG) was normal. Creatine phosphokinase (CPK) was 14,000 IU (normal less than $50 \mathrm{IU}$ ). There was no family history of neuromuscular disease or anaesthesia-related problems and the child had had no previous operations.

No premedication was administered. Anaesthesia was induced with nitrous oxide, oxygen and halothane by face mask, with assisted ventilation. There was no difficulty maintaining a good airway. Maximum halothane concentration attained during induction was two per cent and this was associated with a nodal cardiac rhythm of 100 beats $\mathrm{min}^{-1}$, without change in blood pressure. Axillary temperature increased from $34.4^{\circ} \mathrm{C}$ to $36^{\circ} \mathrm{C}$. Approxj. mately ten minutes after beginning anaesthesia, the T-wave on the ECG was noted to be peaked and a venous blood sample was obtained to measure serum potassium. Within a minute the ECG progressed to widened QRS complexes and then to asystole (Figure)

All anaesthetic agents were discontinued, the trachea was intubated and ventilation was controlled with oxygen. Chest compressions were initiated simultaneously. The patient received repeated doses of intravenous sodium bicarbonate $\left(1 \mathrm{mEq} \cdot \mathrm{kg}^{-i}\right)$, epinephrine hydrochloride $\left(10 \mu \mathrm{g} \cdot \mathrm{kg}^{-1}\right)$, calcium 


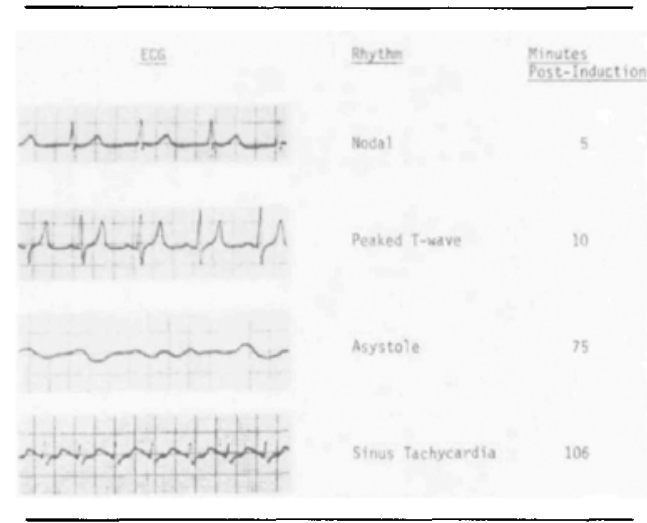

FIGURE Intraoperative ECG events.

chloride $\left(10 \mathrm{mg} \cdot \mathrm{kg}^{-1}\right)$, lidocaine hydrochloride $\left(1 \mathrm{mg} \cdot \mathrm{kg}^{-1}\right)$ and procainamide hydrochloride $(2$ $\left.\mathrm{mg} \cdot \mathrm{kg}^{-1}\right)$. Glucose $\left(\mathrm{lg} \cdot \mathrm{kg}^{-1}\right)$ and regular insulin $\left(0.5 \mathrm{u} \cdot \mathrm{kg}^{-1}\right)$ were also administerd to treat hyperkalaemia. Dantrolene sodium was given three times (total dose $9 \mathrm{mg} \cdot \mathrm{kg}^{-1}$ ) since MH was suspected.

During the resuscitation period, the patient had acrocyanosis, cold skin, dilated and unresponsive pupils and a distended abdomen. There was no masseter spasm or peripheral rigidity. Pink frothy fuid was suctioned from the endotracheal tube. Axillary temperature decreased to $34.6^{\circ} \mathrm{C}$ during the resuscitation. Rectal temperature reached a maximum of $36.9^{\circ} \mathrm{C}$.

A doppler probe secured over a radial artery was used to assess the effectiveness of chest compressions. Cardiac activity alternated between asystole and ventricular fibrillation. There were two episodes of ventricular tachycardia only lasting a few seconds and not associated with any spontaneous blood pressure. External defibrillation was attempted multiple times but was unsuccessful in restoring a normal cardiac thythm. Serial blood samples were obtained initially from an intravenous catheter inserted for this purpose because obtaining arterial access was difficult in the absence of a detectable blood pressure (Table). A catheter was ultimately inserted in a femoral artery by cutdown. Hypoxaemia and hypercarbia persisted despite vigorous hyperventilation with 100 per cent oxygen.

A transvenous cardiac pacing wire was inserted, but was also unsuccessful in restoring effective cardiac contractions. After 90 minutes, a sinus tachycardia suddenly developed and a blood pressure was generated. Dopamine and crystalloid solutions were administered to maintain a systolic blood pressure $>70 \mathrm{mmHg}$. Burgundy-colored urine developed and was treated with additional intravenous fluids, mannitol, and alkalinization of the urine with intravenous sodium bicarbonate. A CPK value taken four hours after resuscitation was $85,000 \mathrm{IU}$ and serum myoglobulin was $800 \mathrm{mg} \cdot \mathrm{L}^{-1}$ (normally none detectable).

Dantrolene sodium $\left(1 \mathrm{mg} \cdot \mathrm{kg}^{-1}\right)$ was administered every six hours for the next 24 hours and gradually tapered over the ensuing two days. The patient remained intubated for four days in order to treat pulmonary oedema, atelectasis and possible aspiration pneumonia. He was discharged from the hospital on the eleventh day. His neurological and physical examination at that time and on follow-up visits up to one year later remained unchanged from before admission. He resumed his normal daily activities and had no personality or behaviour changes.

\section{Discussion}

While the aetiology of the cardiac arrest in this case is not known for certain, there is a good reason to suspect it was secondary to the acute onset of the syndrome of malignant hyperthermia. Hypoxia despite supplemental inspired oxygen, hypercarbia despite hyperventilation, metabolic acidosis, hyperkalaemia, myoglobinuria and massive elevation of CPK are typical findings in this condition. Hyperthermia frequently develops late and may not occur if early circulatory arrest occurs. ${ }^{8}$ Primary pulmonary or myocardial dysfunction can certainly result in problems during anaesthesia in patients with neuromuscular disease, ${ }^{9}$ but there is no evidence that these occurred here.

Most cases of MH in patients with DMD have developed immediately after administration of succinylcholine $e^{1,3,4,7}$ or more gradually with prolonged administraton of halothane. ${ }^{6}$ Some patients first manifested a problem after their operation was completed, while they were in the recovery room. ${ }^{2}$ This case is unusual in that a fulminant episode of MH occurred within ten minutes of the induction of anaesthesia with inhalational agents alone, in the absence of muscle relaxants or other drug use. It is unclear why this occurred. However, this patient 
TABLE Laboratory values

\begin{tabular}{|c|c|c|c|c|c|c|c|}
\hline $\begin{array}{l}\text { Minutes } \\
\text { after induction }\end{array}$ & Events & $\begin{array}{l}\text { Blood samples } \\
\text { venous (V) } \\
\text { arterial (A) }\end{array}$ & $p H$ & $\begin{array}{l}\mathrm{PO}_{2} \\
(\mathrm{mmHg})\end{array}$ & $\begin{array}{l}\mathrm{PCO}_{2} \\
(\mathrm{mmHg})\end{array}$ & $\begin{array}{l}\text { Base } \\
\text { deficit } \\
\left(m m o l \cdot L^{-1}\right)\end{array}$ & $\begin{array}{l}\text { Serum } K^{+} \\
\left(m E q \cdot L^{-1}\right)\end{array}$ \\
\hline 10 & Peaked T-wave & V & 7.20 & 58 & $6 \mathrm{l}$ & 6 & 5.9 \\
\hline 35 & Asystole & V & 7.16 & 24 & 64 & 6 & 8.9 \\
\hline 45 & Asystole & V & 7.08 & 23 & 74 & 8 & 8.9 \\
\hline 50 & Asystole & V & 7.00 & 18 & 75 & 12 & 7.8 \\
\hline 66 & Asysiole & V & 6.94 & 32 & 86 & 15 & 8.4 \\
\hline 75 & Asystole & V & 6.91 & 26 & 79 & 18 & 8.2 \\
\hline 106 & Sinus tachycardia & A & 7.29 & 84 & 42 & 17 & 5.9 \\
\hline 114 & Sinus tachycardia & A & 7.27 & 348 & 38 & 10 & 5.2 \\
\hline 131 & Sinus tachycardia & $A$ & 7.23 & 234 & 35 & 12 & 4.5 \\
\hline
\end{tabular}

had a preoperative CPK of 14,000 I.U. which is high even for a patient with DMD, and he may have been in an active phase of muscle destruction.

The incidence of MH in patients with DMD is not yet established. In a retrospective analysis done by us $^{10}$ of all anaesthetics administered to children with DMD at the Children's Hospital in Boston over the last five years, there were no complications in six patients receiving a "safe" technique (barbiturates, narcotics, nitrous oxide and nondepolarizing muscle relaxants), while there were five anaesthesiarelated problems among 19 patients who received potent inhalation agents. Among these were two cardiac arrests and three additional patients with unexplained fever and/or tachycardia which responded to discontinuation of volatile anaesthetic agents. Recently, we have had good results using regional anaesthesia (including spinal anaesthesia) in these patients.

It is important to emphasize that this patient demonstrates the ability of conventional closedchest cardiopulmonary resuscitation (CPR) to provide adequate circulation for prolonged periods. Although other reports have also documented this fact, ${ }^{11,12}$ there is general pessimism when CPR is necessary for more than thirty minutes. ${ }^{13}$ While outcome is undoubtedly poor after long resuscitation in patients who are debilitated or suffer from multisystem organ failure, such is not necessarily the case in previously healthy patients ${ }^{14,15}$ who develop sudden and unexpected cardiac arrest. CPR in such settings may be successful for prolonged periods when the initiating event is potentially reversible and no absolute limit should be given to the time CPR is warranted.

\section{Conclusion}

This report describes a child with probable DMD who developed sudden cardiac arrest during inhalation of halothane, nitrous oxide and oxygen. Malignant hyperthermia was the likely diagnosis. Patients with DMD should be treated as though they were susceptible to $\mathrm{MH}$ and agents which could initiate MH should be avoided. ${ }^{16}$ With any anaesthetic technique (general or regional), dantrolene sodium should be immediately available.

\section{References}

1 Oka S, Igarshi Y, Takagi A et al. Malignant hyperthermia and Duchenne's muscular dystrophy. Can Anaesth Soc J 1982, 29: 627.

2 Kelfer $H M$, Singer WD, Reynolds RN. Malignant hyperthermia in a child with Duchenne's muscular dystrophy. Pediatrics 1983, 71: 118.

3 Brownell AKW, Paasuke Rl, Elash A et al. Malignant hyperthermia in Duchenne's muscular dystrophy. Anesthesiology 1983, 58: 180

4 Boltshauser E, Steiman B, Meyer A et al. Anaesthesia induced rhabdomyolysis in Duchenne's muscular dystrophy. Br J Anaesth 1980, 52: 559.

5 Ording $H$, Ranklev $E$, Fletcher $T$. Investigation of malignant hyperthermia in Denmark and Sweden. $\mathrm{Br}$ J Anaesth 1984, 56: 1183.

6 Marchildon MB. Malignant hyperthermia. Arch Surg 1982, 117: 349 .

7 Henderson WAV. Succinylcholine-induced cardiac arrest in unsuspected Duchenne's muscular dystrophy. Can Anaesth Soc J 1984, 31: 4, 444.

8 Gronert $G A$. Malignant hyperthermia. Anesthesiology 1980, 53: 395. 
9 Gilroy JH, Gahalan JL, Berman R et al. Cardiac and pulmonary complications in Duchenne's muscular dystrophy. Circulation 1963, 27: 484.

10 Sethna NF, Rockoff MA, Worthen MH et al. Anesthesia-related complications in children with Duchenne's muscular dystrophy. Neurology 1986 36 (Suppl. 1): 152.

11 Damier $G V$, Palminello $L$. Chances of recovery as a result of long periods of external heart massage. Minerva Anesthesiologica 1970, 28: 350.

12 Cleveland J. Complete recovery after cardiac arrest for three hours. N Engl J Med 1971, 284: 334.

13 Bedelli S, Delbanco TL, Cook EF et al. Survival after cardiopulmonary resuscitation in the hospital. N Engl J Med 1983, 309: 570.

14 Aruna JG, Cradio A, Martinez MV et al. Hyperkalemic cardiac arrest, prolonged heart massage and simultaneous hemodialysis. Crit Care Med 1981, 9: 556.

15 Orr DA, Bramble MG. Tricyclic antidepressant poisoning and prolonged external cardiac masage during asystole. Br Med J 1981, 283: 1107.

16 Rosenberg $H$, Heiman-Patterson $T$. Duchenne's muscular dystrophy and malignant hyperthermia. Another warning. Anesthesiology 1983, 59: 362.
Résumé

Un arrêt cardiaque survenant chez un enfant âgé de 5.5 ans suspect d'avoir une dystrophie musculaire de Duchenne est survenu dix minutes après l'induction de l'anesthésie avec halothane, protoxide d'azore et oxygène. Aucun relaxant musculaire n'était administré. L'arrêt cardiaque était associé à une hypercaliémie, acidose, myoglobinurie, une augmentation $d u C P K$ et une augmentation de $1.6^{\circ} \mathrm{C}$ dans la température. L'enfant s'est rétabli complètement après 90 minutes de réanimation cardiopulmonaire. 